\title{
Comparative Analysis of the Turkish and Cameroonian Women's Evolving Participation in Social Life
}

\author{
İsmail Köse ${ }^{1}$ \\ John Madi Madi ${ }^{2}$
}

\begin{abstract}
Women's rights and gender equality are current and vital problems in the world which still need a solid and sustainable solution. This comparative analysis, which at first glance may seem questionable, intends to compare two vastly different countries. Important differences exist between the two nations. One is a member of NATO, a developed great world economic power, a member to G20, and is the first power in the Middle East to have its major economic city, Istanbul, among the most visited destinations around the world. The other nation is the main force in the central African region, a developing country that is currently struggling with this process as it attempts to emerge into the developed world by 2035. At first glance, this comparison seems difficult and it is precisely this difficulty that is orienting this study around a specific factor and actor in the development process of these countries: the social status of Turkish and Cameroonian women. Driving this research is an innovative comparison designed to outline the converging and diverging realities of these nations
\end{abstract}

Keywords: Women, Cameroon, Development, Secularism, Gender Equality

JEL Codes: A31, J11, J12

\section{Kamerun ve Türkiye'de Kadınların Sosyal Yaşama Katılım Gelişiminin Karşılaştırmalı Analizi}

ÖZ: Kadın haklarl ve cinsiyet eşitliği günümüz dünyasında kesin ve sürdürülebilir çözüm bekleyen sorunların başında gelmektedir. İlk başta sorgulanabilir gibi görülen bu karşılaştırmalı çalışma iki çok farklı ülkeyi karşılaştırmayı hedeflemektedir. Karşılaştırılan iki ulus arasında esaslı farklılıklar mevcuttur. Ülkelerden birisi NATO, G20 üyesi olup, gelişmiş bir dünya ekonomik gücüdür ve dünyada en çok ziyaret edilen destinasyonlardan birisi olan İstanbul gibi esaslı ekonomik bir merkeze sahip olup, Ortadoğu'nun önde gelen aktörleri arasındadır. Karşılaştırma yapılan diğer ülke Orta Afrika'nın ana gücüdür, gelişmekte olan bir ülkedir ve bütün çalışmalarıyla 2035 senesinde dünya gelişmiş ekonomileri arasına katılmayı hedeflemektedir. Bütün bu özellikler dikkate alındı̆̆ında her iki ulus arasında karşılaştırma yapılmasının güç olduğu görülür. Buna karşın bu çalışmayı her iki ülkenin gelişim sürecinde özel bir yere ve role sahip olan kadın haklarının gelişiminin karşılaştırılmasından elde edilecek bulgular gerekli hale getirmiştir. Çalışma, yenilikçi bir anlayışla iki ulusun kadın haklarının gelişimi arasında yakınlaşan ve ayrışan alanları analiz etmektedir.

Anahtar Kelimeler: Kadın, Kamerun, Kalkınma, Laiklik, Cinsiyet Eşitliği

JEL Kodu: A31, J11, J12

Geliş Tarihi / Received: 03/07/2020

Kabul Tarihi / Accepted: 25/03/2021

\footnotetext{
Special thanks to Mrs. Karin Beltran for her proof reading the text.

${ }^{1}$ Dr. Associate Professor, Karadeniz Technical University, Faculty Member in the Department of International Relations. ismailkosetr@ktu.edu.tr, orcid.org/0000-0002-8489-5088. Special thanks to Mrs. Karin Beltran for her proof reading the text.

$2 \mathrm{PhD}$ Candidate, Karadeniz Technical University, Faculty Member in the Department of International Relations. madi2032@yahoo.com, orcid.org/ 0000-0002-5385-9404.
} 


\section{Introduction}

Feminist theory especially after the mid-20 ${ }^{\text {th }}$ century supports women's participation in social life. However, there are several challenges preventing gender equality in societies (Sands and Nuccio, 1992: 489). The distance between Turkey and Cameroon, as the crow flies, is approximately 2.825 miles (4.547 $\mathrm{km}$.). Turkey's population is about 83 million (TUİK, 2019) while Cameroon's population is about 25.64 million. The percentage of Muslims in Turkey is nearly 95\% and in Cameroon is 20.9\% (CIA Fact Book, 2008). Despite its dominant Muslim population, and differing from other Middle Eastern countries, Turkey is a developed country, and a secular democratic state. In contrast with its development level women's participation in social life and the status of women, gender equality, etc. are still problematic issues in Turkey. Similarly, for Cameroon, located in the central region of Africa, and a country still in the development stage, women's rights and gender equality are at a crucial point and in need of an urgent solution. In contrast with the huge gap between the country's economic and technologic development levels, the status of women in both countries are almost identically problematic, meaning that this case needs a detailed analysis and comparison.

The Turkish Republic was founded in 1923 by Atatürk on the ashes of the Ottoman Empire. This former superpower ruled the important part of the world such as the north of Africa, the Middle East and Eastern Europe for not less than a half millennium TGNA Minutes Book; Vol. 2, 8 December 1923: 316-317). Founded after two successive dramatic wars, Turkey has undergone fluctuating economic and social development, including several devaluations of the Turkish Lira (for example, in 1994 inflation reached 125\%) or the attempted coup of July 15th, 2016. However, throughout all these struggles, Turkey has always found the key concepts and decisive solutions to maintain its stability and reinforce its readiness to move forward.

On the other side, Cameroon, which won its independence in 1960, is a former territory which had been placed under the mandate of both Great Britain and France, supervised by the United Nations from 1945 to 1960 and previously under the League of Nations from 1920 until 1945 (Nfor N Nfor, 2014: 161). This country has experienced reunification and federalism and finally became a united country on May 20, 1972. While Cameroon and Turkey took different routes to statehood, they have experienced some similar economic and social issues. These include the devaluation of Cameroon's currency in 1994 to the point that national prosperity was greatly undermined. Additionally, both nations have experienced terrorist organizations on their soil - the PKK (Kurdistan Workers Party) in Turkey and repeated incursions into Cameroon by the Nigerian Islamic terror group, Boko Haram.

As previously mentioned, Cameroon and Turkey are two countries that have faced and are still facing some similar struggles in their process of consolidating and 
strengthening their welfare and security. However, these respective national efforts of construction and achievement have witnessed the inclusive participation of several actors who, according to their capacities and abilities, have played a certain role in their specific domain to implement the spirit of togetherness and the emergence of their homeland. Among these actors are identifiable political movements, the workers of public and private sectors, traders, businesspersons and women.

In spite of the fact that most of the time, great male figures and references are used to mobilize and to symbolize the work being done to lift up the nation, like Kemal Ataturk, and other political leaders in Turkey or Ruben Um Nyobe, Ahmadou Ahidjo and Paul Biya in Cameroon, there are some well-known and identifiable female figures recognized as icons in the development of their countries. Evaluating both countries' realities is the principal motivation and raison d'être of this research paper, which is focused on women's movements and their participation in the social life of their country. By comparing the deeds and acts of women from the two above-mentioned states, and by questioning the role played by this specific gender in the maturation of their respective country, we can better understand the development of these two nations.

The aim of this analysis is to conduct a critical comparative analysis on the evolving of Turkish and Cameroonian women in the policy-making process of their respective countries. This analysis aims to be more encompassing by identifying the woman in what she is first, a human being, before claiming or disclaiming a gender supremacy or minority, under the light of the Women in Development approach which emerged in the 1960's. It is one of the principles drawn by Hermann Baumann in 1928 in his production the Division of Work According to African Hoe Culture (Baumann, 1928: 319).

Geographically delimited in Cameroon and Turkey and temporally circumscribed after the Cold War era, from the years 1990 marking a new international environment until the years 2018, the specificity and originality of this research paper is based on the fact that it is at our disposal the first document which analysiss and compares the situation, actions facts and deeds of both Cameroonian and Turkish women in the development of their respective country. More precisely, from our various researches in libraries and online, we have not found a production specifically putting together, analyzing or comparing the Turkish and Cameroonian women activities and the impacts of their deeds in the structuration of their country. This paper may therefore presents itself as a pioneer in this field and constitute a modest source of analysis and explanation on the importance of Turkish and Cameroonian women in the development of their homeland.

However, through this comparative analysis, more than drawing a simple and naïve photography or compilation of the realizations of women in the two identified countries, will rather be question of comparing the various sectors, by identifying the strengths and the weakness of every side of activity in order to 
demonstrate with facts and figures the positive and negative sides constituting the engagement of Turkish and Cameroonian Women towards their respective country. It is the reason why to conduct this analysis, the research question draining this comparative analysis intends to identify and understand the converging and diverging points in the action of this side of the national population on their respective field of actions. More precisely, the research question through the comparative method and the collecting of data technique which will be mobilized to conduct this work is what are the common and the disparate identifiable realities in the movement and actions of Cameroonian and Turkish women in the development of their country? What are their converging positions and actions? What is the level of their participation into social life? What are the ones distinguishing them?

Obviously, which can be easily identifiable in the Cameroonian and Turkish environment, the realizations of engaged women impacting the emergence of their country. However, the profound analysis that will be done may outline some important distinctions and differences in the implementation of these women decisions for the sake of their country to mark some gaps that may be filled by the respective national decision makers.

On our process to identify the literature review, having seen like works or publications, after several searches and having not found any specific literature directly related to a comparative analysis of this nature including the women of both countries in their deeds and facts on the social economic and political progress and the incidences on these actions on their respective countries, this paper aims to bring out if there are any significant differences and similarities of both nations and present itself as a pioneer, an innovator of this approach. Organized around two parties, the arguments of this study will gravitate around the similarities on the economic politic social and economic realities in the Turkish and the Cameroonian context on a side and on the divergences or gaps marking the specificities of each milieu by another one. Considering the gap between democratization, modernization, economic wealth and development levels at the first stage it is naturally expected that the status and social life participation of Turkish women is much higher than the Cameroonian women. The study will prove that actually this premise needs further discussion.

\section{Similarities between the Turkish and the Cameroonian Women in the Engagement in Favor of the Development of Their Countries}

On the Political side: In democratic countries women participation in political life generally is still far from the ideal level. For instance in Western Europe, at $27 \mathrm{EU}$ countries women participation on average in legislative fluctuates around $22.85 \%$ (Stockemer, 2007: 479-480). The political intervention of women from Cameroon and Turkey in the political evolution of their country will be questioning the regards of women on the political parties movement, their dedications to the respect of Human right and their political responsibilities such as participation in 
the electoral process and the free and fair expression of their willingness for the wellbeing of their nation.

One of the motivations of the Turkish women to engage themselves in the politics affairs of their country can be identified in the deeds of the founder of the Republic of Turkey in 1923, Kemal Ataturk. More precisely, willing to modernize the country after its re-foundation, this main reference of the Turkish modern history has decided to grant to Turkish women some new rights. The right to participate to open fair and free elections is part of the reforms made by Ataturk. In fact before many countries worldwide, the Turkish women have been authorised to vote since 1934 which is 10 years before the French women in 1944 and 37 years before the Switzerland women (TGNA Minutes, 1934: 2-3; Cumhuriyet, 1934: 1). Another element that reinforces the engagement of women and re-up their motivations has been the declaration of the equality of gender in 1926 just three years after the creation of the Republic accompanied by the prohibition of polygamy and the right to end an unwanted or unhappy marriage.

In Cameroon where in the census by the World Bank, women represent $50.6 \%$ for a $49.6 \%$ of men, the Cameroonian women as presented by Rose Ndengue (2016: 154) in her Cameroonian Women mobilization in the French Cameroon from 1940 till 1950 have inherited of the system in vogue in the former French Metropole the French Republic. Taking into account their education level, Cameroonian women have intended to mobilize the other women during the colonisation and the period after the independence in 1960. One of the manifestations of the engagement of women in politics has been noted with the creation on the DUCW Democratic Union of Cameroonian Women in 1946, the creation of CAMWAS Cameroonian Women Association, the CUA Cameroonian Union Association requiring the amelioration of women conditions while the CAMWAS was seeking for the acceptance of women in politics. An important name is that era preceding the independence period is known such as Laurence Eteki Maladi with her dedication in 1946 to another image of Cameroon seen by women (Germain, 2018: 154). As above-mentioned, prerequisites have constructed the path that determined a further engagement of Turkish and Cameroonian women in politics at all the level as will be developed in the next points.

The women in political races: With a political environment counting not less than 81 political parties, Turkey is moving with a nine political movement represented in the National Assembly. Among them, the HDP (Peoples democratic Party) cochairs of Sezzai Temelli and Pervin Buldan, the AKP (Justice and Development Part) lead by Recep Tayyip Erdogan, the CHP (Republican Peoples Party) managed by Kemal Kilicdaroglu, the DP (Democrat Party) of Gultekin Uysal, the IYI (Good Party) of Meral Aksener, the BBP (Great Union Party) of Mustafa Destici, the SAADET (Felicity Party) of Temel Karamollaoglu, the MHP 
(Nationlaist Movement Party) of Devlet Bahceli and the İşçi (Labour Party) of Erkan Baş (https://sonuc.ysk.gov.tr/sorgu, 2018).

The main symbol is the presence among these nine major political parties of Meral Aksener, the only women leader of a popular political party since the starting point of her presidency on October $25^{\text {th }}, 2017$ which participate in presidential and local consultations. On a personal side, Akşener has recorded in the last presidential election of June $24^{\text {th }} 2018,4.958 .230$ votes representing $7.29 \%$ of the national percentage and has resulted as the $4^{\text {th }}$ behind R. Tayyip Erdogan from AKP who obtained $52.59 \%$, Muharrem Ince of CHP the second with $30.64 \%$ and Selahattin Demirtas of HDP with his $8.40 \%$ (https://sonuc.ysk.gov.tr/sorgu, 2018).

In the rally of the Grand National Assembly in 2018, Meral Aksener political party has obtained about six million votes representing $9.96 \%$ and has come $5^{\text {th }}$ in the final general ranking giving to her association 39 members of parliament out of a total of 600 parliamentarians to the Turkish Grand National Assembly (TGNA) led by the AKP with 291 parliamentarians, the MHP with 49, the BBP representing the opposition with 246, the CHP 140, the HDP 62, the SP 6, the TIP 2 , the DP 1 , the independent 3 with a 10 vacant places. The women representation in the TGNA is AKP: $18.21 \%$; MHP: $8.16 \%$; BBP 0\%; CHP: $12.14 \%$; HDP: 40.32\%; $\quad$ SP: $\quad 0 \% ; \quad$ TIP: $0 \% ; \quad$ DP: $0 \%$ (https://www.tbmm.gov.tr/develop/owa/milletvekillerimiz_sd.dagilim, 2018). The average women representation in the TGNA is much lower than EU which is $17.29 \%$. Interestingly the highest women level belongs to the HDP which mostly represents the underdeveloped south-eastern part of Turkey and accuses focus on encouraging ethnic terrorist organization(s) targeting the Turkey's integrity. Another point which deserves the attention is the fact that women representation in five major parties is less than $(7,69 \%)$ in a woman lead Meral Aksener's IYYI Party.

Madam Aksener is a newly emerged political actor movement leader and the only Turkish woman leading a political party throughout the country. The political movement that Aksener animates, even though it records no metropolitan municipalities, is counting 25 out of 1351 district municipalities, out of 1251 provincial councillors, out of 20.498 municipal assemblies. Despite this relative score, it is obvious that Madam Aksener is a major political figure in Turkey, as in Istanbul Metropolitan elections of 2019 could change the winner.

As same as in Cameroon, some important women figures contributed with their own specificities to the political movement of the nation. Women representation in Cameroon National Parliament (CNP) is $31.10 \%$ by 2017. The level of women representation was $14.40 \quad \%$ in the 1990's (https://www.indexmundi.com/facts/cameroon/indicator/SG.GEN.PARL.ZS, 2019). Remarkably in contradiction with the development levels percentage of 
women in CNP almost double of Turkey. This case clearly indicates Turkey's inability on gender equality in legislative representation.

Edith Kahbang Walla, the Cameroonian chief of enterprises was recognized by the World Bank in 2007 as one of the 7 more influential women entrepreneurs in Africa and among the 150 women who move the world by the magazine Newsweeks, is a notable politician head of the Cameroon People Party the CPP with which she has participated in the 2011 presidential election in the country (https:// www.journalducameroun.com/en/kah-walla-boycott-presidential-election, 2018). Starting her big steps in politics in the opposition political party the Social Democratic Front, in 2007 under which she will be elected as municipal councillor, she has finally decided to quit that party due to a misunderstanding.

Presented as the first ever women who stood for a presidential race in Cameroon, Kah Walla in the 2011 contest reached $6^{\text {th }}$ out of the 23 candidates with a $0.72 \%$ of general votes. She is one of the inspirers of women in politics in the country and a beneficiary of many international recognitions such as the Vital Voices Global Leadership Award in public life, the Diane Von Furstenberg Award or the Vital Voice Vanguard Award in 2015 (https://www.afrikipresse.fr/politique/yaounde-l-opposante-edith-kah-wallah-etdes-membres-de-la-coalition-stand-up-for-cameroon-arretes?pr=72166\&lang=fr, 2018). As mentioned in the cultural side of this analysis Françoise Foning who has been a major figure of the governing political Party the CPDM, as the mayor of Douala five municipal council and another symbol of Cameroonian women in politics.

Henriette Ekwe is a well know Cameroonian figure who has fought for the freedom of press because she is before everything a journalist but also for gender equality, the respect of human rights and the promotion of the good governance. Political activist, Madame Ekwe has been awarded in 2011 the international Women of Courage Award in United States of America by the former Us Secretary of State and First Lady Hilary Clinton who recognized in her a symbol of fight for the well-being of her community. The human rights abuses that she condemns and the fight against corruption on Cameroon that she promotes has driven her into face repression torture and being presented to military jurisdictions to compare before the law.

The members of Government, Parliamentarians and States Societies Chiefs: In Turkey as in Cameroon, women are part of the governing bodies which organize, regulate, and guarantee the evolution of the nation. This gender representation is observable at the level of Members of Government. In Cameroon, we have less than 10 members of Government that are women. Eleven women Ministers of the Republic were appointed by the January 2019 Cameroonian Presidential Decree (https://www.spm.gov.cm/site/?q=fr/content/organisation-du-gouvernement, 2019). 
Madame Kendeck Pauline Irene Nguene who is the Minister in Charge of Social Affairs, Madame Pauline Egbe Nalova Lyonga, the Cameroonian Minister of Secondary Education or Madame Celestine Ketha Courtes who was the former mayor of the Bagante urban council, a city in the western part of the country, and actual Minister of urban Development. Madame Libong Li Likeng is the Minister of Posts and Telecommunications, Madame Ondoa Obama Marie Therese the Minister the Promotion of the Woman and the Family and the Minister of Scientific Researches and the Innovation Madame Tchuinte Madeleine. As Delegate Ministers, Madame Mbah Rose Acha Fomundang Gwari is the Minister Delegate at the presidency of the Republic in charge of High State Public Audit, Madame Ananga Messina Beyene Clementine is the Minister Delegate to the Minister of Agriculture and Rural Development. At the level Secretary of State, Madame Kilo Vivian Asheri is the Secretary of State to the Minister of Basic Education, Madame Koulsoumi Alhadji Boukar, the Secretary of State to the Minster of Forest and Livestock and Madame Dibong Biong Marie Rose the Secretary of State to the Minister of Urban Development (https://www.prc.cm/en/news/1055-ministerial-council, 2019). 14\% of the entire cabinet is dedicated to women presently on duty.

Turkan Akyol is the first Turkish woman Minister of the Republic born in 1928 in Ankara. She was minister of Health and Social Aid Ministry during the interim government of Nihat Erim in 1971. Madam Akyol, 21 years after her reappointment as the Minister of State is responsible for Women Affairs in 1992 was in office until 1996. Another interesting female figure in Turkish politics is Tansu Ciller, the first ever woman Prime Minister from June 13th 1993 till March $6^{\text {th }} 1996$ under the Presidency of Suleyman Demirel, Chief of the True Path Party for more than nine years and Deputy Prime Minister and Foreign Affairs Minister from June $28^{\text {th }} 1996$ until June $31^{\text {st }} 1997$. Turkey has lost a major political symbol of its history, the recent Turkish Government formed by the President Recep Tayyip Erdogan and his Vice President Fuat Oktay on July $9^{\text {th }} 2018$, also known as the $66^{\text {th }}$ Cabinet is composed of 16 Ministries. Among them two women are represented. Madame Zehra Zumrut Selcuk is the Minister of Labor, Social Services and the Family; Madam Ruhsar Pekcan, Minister of Trade (RoTOJ, 2018). The percentage of women in the Cabinet is $11 \%$, almost half of legislative representation in the Parliament (17,29\%). Taking into consideration the recent refoundation of the Turkish government formed by 16 members, only two women are in charge which makes $12.5 \%$ of the Government women.

In Cameroon, at the level of Chief Executive Officer of National Companies: Before becoming the Minister of Post and Telecommunications, the actual Minister of Post and Telecommunication, she was the Director General of the Cameroonian Custom. We also have the case of Madame Achidi Ashu since December 2018 who is the General Director of Cameroonian Telecommunication, a State Company in charge of telecommunications, after being for several years branch Director and high ranked responsible in the same company. The National 
Investment Society (SNI) created in 1964 is the Cameroonian State corporation in charge of the mobilisation and the orientation of national and international investments. Since 2003, Yaou Aissatou a Cameroonian woman born in 1951, President of the Woman Branch of the Cameroonian People Democratic movement the CPDM, the governing party in the country, who has been the first ever Cameroonian women to serve as a Minister in the country, daughter of the Tcheboa King in the Northern part of the country is serving in the NIS since 1979 as Deputy Director in charge of Finances. She has been the Minister in Charge of Women Condition (https://guide2womenleaders.com/Cameroon.htm, 2018).

In the same range, since December 2018, the Societe Camerounaise des Depots Petroliers has been managed by the former deputy Director of the Hydrocarbons Prices Stabilization funds, Madame Moampea Mbio Veronique Manzoua. That National Company is the one in charge of storing the national petrol. It is the agency in charge of providing all the petrol and oil stations and necessary fuels for the national consumption needs. It is the agency which determined the energizing of every engine using carbons in Cameroon.

The local Authorities: In Cameroon there are up to 69 women in the regional government of the country. There are 3 Divisional Officers out of 58, 15 SubDivisional Officer out of 360, 14 deputy Divisional Officers, 27 Deputy Sub Divisional Officers, 1 chief of Governor Cabinet, 5 Chief of Division and 4 Regional Services Inspectors. It marks the reup of the women in the territorial administration and commandment (https://www.journalducameroun.com/cameroun-ces-femmes-aucommandement/, 2019). In the west Region of the country, Antoinette Zongo Nyanbonne is the Nkoung Nkui Divisional Officer. She is the first women to be appointed as Divisional Officer in Cameroon. In the south in the Vila Division, Rachelle Ngah Zang is the Divisional officer of the locality.

In Turkey, 3 female governors of province are actually conducting the affairs of their administrative units. Since June $16^{\text {th }}, 2016$ Madame Tugba Yilmaz is the governor of the Province of Yalova, having a population estimated at 251.203 in 2017 by the TUIK (2017). Madame Esengul Civelek in the north west province of Kirklareli, located in the Marmara Region, having a population of 360.860 individuals (TUIK, 2018). Yasemin Ozata Cetinkaya is the Governor of the Historic Province of Sinop by the Black Sea coast having an estimated population of 219.733 inhabitants (TUIK, 2018). In local government some women are municipality mayors out of the 81 main cities of the country as resulting of the recent March 2019 local elections. Madame Fatma Sahin from the AKP political Party has won the election in the Gaziantep municipal council, Madame Ozlem Cercioglu, in the Aydin Municipality. Representing the HDP party, Madame Bedia Ozgokce Ertan is the mayor of the Van Municipality when Madame Berivan Helen Isik is the Siirt one, a city of 331.670 inhabitants (https://sonuc.ysk.gov.tr/sorgu, 2019). As it is seen in the state administration 
percentage of women state administrators also interestingly is higher in Cameroon than in Turkey.

\section{On the Economic side:}

Throughout this second segment related to the economic side of the national life of Turkey and Cameroon will be put together in order to outline the similar points and the actions drawn by both citizens in the economic growth of their respective nation.

Turkish and Cameroonian women are well represented in the international business environment: In Cameroon, according to the pan-African magazine Jeune Afrique, five Cameroonian women are listed in the top 50 most powerful and influential businesswomen around the African continent. Occupying respectively the $14^{\text {th }}$, the $24^{\text {th }}$ the $26^{\text {th }}$ the $34^{\text {th }}$ and they $48^{\text {th }}$ global rank these women present to the international community the guarantee that the Cameroonian women are among those businesswomen who may rely on for a better future (https://www.theafricaceoforum.com/en/ressources/exclusive-list-50influential-women-in-business/, 2019).

It is the case of Madame Patricia Bertholot who is the Deputy Director General of the Anonym Society the Brasseries of Cameroon specialised in the agro industry sector. In 2016, she acceded the Castel branch of SABC with charge of Deputy General Manager after having been for a two years period the Manager of the Society Diageo moving in the same sector in Seychelles. Madame Kate Fotso who is the General Manager of the Telcar Cocoa company, is the spouse of Andre Fotso, the former Cameroonian head of Cameroonian General Managers Associations and the first Cocoa exporter of Cameroon. Madame Elisabeth Medou Badang is the General Manager of the most important telecommunication company in Cameroon. The Cameroonian branch of the French Telecom Orange. Previously responsible for the same agency in Botswana in East Africa, she is the first women since 2013 who is a manager of a telecommunication Company in the country. Madame Collette Jeanine Minka is the interim general manager of Emploi Service and an important reference on the class of Cameroonian businesswomen from who a certain know-how is collectively recognize. Madame Rebecca Enonchong is the Chief Executive Officer of AppsTech Group Inc specialised in the informatics system and services. Having developed a partnership with the giant Oracle she has set representations of her company worldwide (http://africanmediainitiative.org/board-members/, 2019).

From another angle, the National Institute Statistics of Cameroon in its 2012 report present the rate of women engagement at $82.4 \%$, when the men's one is at $87.3 \%$. This 2012 status is presented as better than the 2007 rate with a women activity estimated at $78.8 \%$ according to the value of the International Labour Bureau (https://www.unicef.org/infobycountry/cameroon_statistics.html, 2015). In Cameroon, like in Turkey many women associations regrouping women from 
different sensibilities and having in common the sense of busines have been organized and held activities. It is the case in Cameroon of the Women Entrepreneurs Association which aims to unite the local businesswomen and helping them to face their economic constraints or difficulties by providing to them some internship and same courses on commercial skills by establishing connections and linkages with some others women networks and by setting better approaches in the export and import services facilities (http://www.webuildcameroon.com/en/homepage/, 2019).

It is also the case of the Cameroonian Businesswomen Group known as GFAC. With no less than 480 Cameroonian businesswomen members, the GFAC has been created in 1985 in order to regroup the women wishing to expand their business in Cameroon and abroad. Another Cameroonian Businesswomen group is the CWBLA. The Cameroon Business Leaders Association has been created in Douala in 2017 by the willing of Madame Adelaide Ngale Miono, a woman chief of Enterprise specialised in Public Work and adviser in the Cameroonian most important Business Organisation the GICAM or Cameroonian Inter patronal Association (http://mimimefoinfos.com/2019/03/08/cameroon-womenentrepreneurs-on-the-rise-top-five-to-watch-in-2019/, 2019).

The same atmosphere is observable in Turkey where women are putting together their abilities in order to have a collective promotion of their enterprises and their activities. One of the main organisations is the Turkish Businesswomen Association TIKAD created in 2004 and managed by 13 important figures of the local economy led by Madame Nilufer Bulut. This association intends to promote the women leadership in all the economic sector of the country in regard of the aim to assure stable growth of the country but also to reinforce the participation of these women in the public decision-making and the amelioration of the democratic environment. The American magazine Forbes in its publication related to the ranking of most powerful women around the world. In the list first ranked Angela Merkel the German Chancellor, at the $64^{\text {th }}$ rank is Madame Guler Sabanci. Madame Sabanci is presented as coming from the third generation of the wealthier family in Turkey (http://www.tikad.org.tr/home.html, 2019). She is Chief Executive Officer of the Sabanci Holding, the second most important Holding in the country with a net worth estimated at 16.5 milliard USD in 2015. Through her can be identified the impact of Turkish businesswomen in the development of their country.

On the Cultural side: On the cultural side, there are some major Turkish and Cameroonian figures who try at their level to give a positive image of their country worldwide. Knowing the impact of a country image on the international milieu these actresses of the national development are as same as the members of government or other political party leaders representing this force leading the development of their respective nations. In Cameroon, these women are Madame Miano Leonora who is a writer. She was born in 1973 in Douala in Cameroon and 
is an author publishing in well reputed edition press houses such as Grasset, the Arc Editor, Plon, Robbert Laffon or Flamarion. By editing this Cameroonian intellectual, the voice is being given to a promoter of the Cameroonian Know-how specialities. Madame Miano has been granted the Goncourt Price of Lycee, Louis Guilloux Price, King Chavez Parks Visiting Professorship from the University of Michigan Ann Arbor in 2012, the Rene Fallet Price, France Culture, Liberation, the Bernard Palissy Price, the Black African Literature Price among others been so distinguished it is her country of origin which beneficiated from this international recognition. Those distinctions are among the most important distinctions in the francophone world and the French literature (https://www.lemonde.fr/livres/article/2013/11/06/le-prix-femina-decerne-aleonora-miano_3509073_3260.html, 2019).

Madame Francoise Mbango who was born in 1976 is a Cameroonian athlete who specialised in the triple jump. She was the first ever Cameroonian athlete to obtain the golden medal in an Olympic tournament. She double medalled in 2004 and in 2008. Madame Denise Epote Durand born in Nkonsamba in 1954 is one of the figures of Cameroon Journalism. Bearing the double nationality French and Cameroonian, she is the General Manager of the African Branch of the French Television TV5 World. She is distinguished as part of the most valuable personalities in France, in Senegal, and in Cameroon.

Madame Sally Nyolo is a writer and singer is a Franco Cameroonian artist born in 1967. Having won the 1997 RFI discovery Price she is one of the promotors and defenders of the Cameroonian rhythms worldwide. Madame Pany Irma born in Douala in 1988 is also a well-known singer contributing at her level to the promotion of the cultural image and diversity of Cameroon. Madame Francoise Foning who is at the same time a successful entrepreneur and businesswoman is referenced by Wikipedia as the most significant post-colonial Cameroonian woman in action out of the most active women in politics in the country. Mayor of the Douala $5^{\text {th }}$ urban council this important figure has been twice the president of worldwide association of women Chief of Enterprise, Vice Executive president of African businessmen, Vice president of Francophone Business Forum, and president of African Women Entrepreneurship network. She is on the international business environment as a reference lifting the credibility of Cameroon. Madame Henriette Ekwe can be identified in the same range but will be better presented in the political section. Madame Chantal Biya who is the actual Cameroonian First Lady is the UNESCO goodwill Ambassador. President of the Chantal Biya Foundation and President of the African Network which fight against HIV, one of the most dangerous diseases around the world. Madame Alice Nkom who is a Cameroonian lawyer is the first ever women at the Cameroonian bar. Elected in 2012 by the New Yorker as an exceptional personality she is well known as a defender of the causes of homosexuals and LGBT. 
In Turkey, on the cultural aspect, there are many figures that by their individual actions contribute to the affirmation of the destination Turkey. The American internet site Top Beauty has selected the 100 most beautiful women around the world. In the top 3 are found the American Alexandra Daddario, the Australian Miranda Kerr and another American Gigi Hadid, five Turkish women are present in this global ranking. Tugba Buyukustun ranked $17^{\text {th }}$ of the most beautiful women, Meryem Uzerli $40^{\text {th }}$, Hazal Kaya $80^{\text {th }}$, Fahriye Evcen $84^{\text {th }}$ and Serenay Sarikaya $88^{\text {th }}$. Having ranked nationally in this sort of listing is a promotion to the local tourism attracting visitors curious to discover the country of origin of the identified persons. It is therefore a non-negligible plus for the country (https://balcilar-blog.com/?p=18662, 2019).

On another side, the important women figure Sabire Aydemir born in 1910 - 1991 is considered as the first ever Turkish women vet due to her passion for domestic animals. An occupation considered reserved for men. In 1984 as a symbol of national recognition the TGNA granted to her a decoration at the occasion of the $50^{\text {th }}$ anniversary of the right to vote for women. Hatice Nuzhet Gokdogan born in 1910 - 2003 is the first Turkish woman astronaut and has decisively contributed to the emergence of research in astronomy in Turkey. Married to the co-founder of the Istanbul Technical University ITU, she has been the first woman dean in the faculty of astronomy in the university. She created the Turkish Society of Mathematics in 1948 and the Turkish Women Association in 1949 and founded the Turkish Astronomy Society in 1954 (Matematik Dünyas1, 2003: 40-41).

Sair Nigar born in 1856-1918 is an important reference of the Turkish Ottoman Empire poetry who has been permanently cited in journals and magazines. She was able to express herself in eight languages such as Greek, French, Arab, Persian, Hungarian, Italian, German and Armenian (Baycanlar, 2018: 221-223). Semiha Es born in 1912 - 2012 is known as the first Turkish professional women photographer and the first women war photographer around the world. She has covered the Korean War for the Turkish journal Hurriyet. Selma Emiroglu born in 1927 - 2011 is the first Turkish woman caricaturist. She started painting at the age of one year and half. The common point with the above-mentioned personalities is the fact that all of them have contributed to the emergence and development of their country in their respective sector of predilection. They have been innovators, promotors or just passionate people who by their deeds have impressed their contemporaneous and have encouraged them to interest themselves in the global effort of building a nation.

On the Social side: On the social side we will take into consideration major aspects such as education, sanitary, social life and infrastructures. In short in all the aspects drawing a better living condition for a human being.

The early marriage: According to the report of UNICEF 2017 Report on Child, early marriage around the world represents a total of 82 million girls getting married before reaching the age of the majority consensually limited at 18 years 
old (UNICEF Annual Report, 2017: 7-44). Both Turkish and Cameroonian women are concerned by the early marriage phenomena which has a direct consequence. Taking girls out of the educative system which with a better level of education would have been a plus for the development of their country. According to the Turkish Civil code related to the family issue 2001, even if there are exception mentioned by the articles 11 and the article 117 reducing that age to 17 with the regard of parents consents or to 16 years when some particulars and exceptional circumstances have been identified by the granting authorities, the minimum required age authorizing a young girl to get married is 18 years old (RoTOJ, 2001).

To monitor the Situation, at a Governmental level has been created in Cameroon the Ministry of Woman and the Family in charge of the protection women and the consolidation of the family. The same configuration has been done in Turkey with the creation of the Turkish Family Ministry. As a private initiative, to fight against the phenomena of child marriage, the Turkish Women association Federation TKDF is participating to the extermination of this thread to the emancipation of the Women. In Cameroon the association RENATA known as National Aunties Network is trying at its level to reduce the impact of young child abuses and more precisely the young girl (https://plateforme-elsa.org/structure/renata/, 2019).

\subsection{Differences between the Turkish and the Cameroonian Women in the Engagement in Favor of the Development of their Countries}

Almost a descriptive approach has been presented in the first step of this research paper addressing the realities of women engagement in favour of the wellbeing of their respective citizens in Turkey and in Cameroon. To make this solid analysis more interesting it is important to use a critical method to question the real incidences of these participations and outline the gaps, the best and worst sides of each studied case through this second part pointing out the differences:

On the Political side:

Table 1: The evolution of women participation in political activities 2008-2018

\begin{tabular}{|l|l|l|l|l|l|l|}
\hline & \multicolumn{3}{|c|}{ Turkey } & \multicolumn{3}{c|}{ Cameroon } \\
\cline { 2 - 7 } & 2008 & 2013 & 2018 & 2004 & 2011 & 2018 \\
\hline $\begin{array}{l}\text { Presidential Elections } \\
\text { Candidates }\end{array}$ & - & - & 1 & 0 & 2 & 0 \\
\hline
\end{tabular}

Discussion: In the recent presidential election in Turkey held in 2018, only one woman was officially challenging the President Erdogan. It was the IYI party Leader Meral Aksener who obtained 3.649 .000 votes $7.29 \%$ (https://sonuc.ysk.gov.tr/sorgu, 2018). In Cameroon in the 2011 presidential elections, 2 women stood for the final rally. It has been the case of Esther Dang from the Bloc of Reconstruction and Independence of Cameroon having obtained 15.775 votes representing $0.33 \%$ and Edith Kahbang Walla from the Cameroon Peoples Party who obtained 34.639 votes equals to $0.75 \%$. None has been 
candidate in the 2018 presidential elections (https://www.bbc.com/pidgin/tori45100451, 2019). In both countries women participation in the presidential rally is very low and none of those candidates are drawing good chances to be President of the Republic. Admittedly in both countries since their foundation there has been no women president. In Turkey there was only one women prime minister during the years of 1993-1996. Below table gives solid comparative analysis on women in high ranking administration offices.

Table 2: Women in Responsibilities in 2018

\begin{tabular}{|c|c|c|c|}
\hline \multicolumn{2}{|c|}{ Events } & Turkey & Cameroon \\
\hline \multicolumn{2}{|c|}{ Presidents of Republic } & 0 & 0 \\
\hline \multicolumn{2}{|c|}{ Prime Minister } & 0 & 0 \\
\hline \multicolumn{2}{|l|}{ Ministers } & $2 / 16(12 \%)$ & $11 / 73(15 \%)$ \\
\hline \multirow[b]{2}{*}{ Parliamentarians } & Senators & - & $25 / 100(25 \%)$ \\
\hline & Deputies & $103 / 600(17 \%)$ & $55 / 180(31 \%)$ \\
\hline \multicolumn{2}{|l|}{ Governors } & $3 / 81(4 \%)$ & $0 / 10(0 \%)$ \\
\hline \multicolumn{2}{|l|}{ Divisional Officers } & - & $3 / 58(5 \%)$ \\
\hline \multicolumn{2}{|c|}{ Sub Divisional Officers } & - & $15 / 360(4 \%)$ \\
\hline \multicolumn{2}{|c|}{ Mayors } & $3 / 81(4 \%)$ & $28 / 374(7 \%)$ \\
\hline
\end{tabular}

Discussion: This table stating the presence of women in the strategic level of decision of their respective country presents some relevant facts. In Turkey and in Cameroon no woman is President of the Republic. None is Prime Minister. At the level of Ministers, out of 16 Ministries in Turkey, 2 are women. It represents $12 \%$ of the whole cabinet dedicated to women. In Cameroon, out of 73 Ministries, 11 are women and represents $15 \%$ of the Cabinet. In comparison to the rate in Turkey the conclusion states that there are more women Ministers of the Republic in Cameroon than in Turkey. In addition remarkably in Cameroon at the Parliament there are 25 women in a total of 100 senators which represent $25 \%$ of the senate represented by women. In the National Assembly, there are in Turkey out of 600 deputies, 103 women equal to $17 \%$. In Cameroon there are 55 women out of a total of 180 deputies. It represents $31 \%$ of the National Assembly members. At this level of representations in the Parliament, the conclusion drawn present that there is almost the double of women in the Cameroonian Parliament than in the Turkish one. As the same women percentage of mayors in Turkey 4\%; while in Cameroon is $7 \%$. Only related to the Territorial commandment, there are in Turkey 3 women Governors out of 81 while in Cameroon there are 0 women out of 10 governors. With a percentage of $3 \%$ of women governors of Province, the Turkish women are better represented in the high-level Territorial Commandment than the Cameroonian case with $0 \%$ of women Governors.

At the divisional representation level, data wes not available for the Turkish case while in Cameroon there are out of 58 divisional officers 3 women representing $5.1 \%$ of the body. Number of women divisional officers in Turkey is 16 out of 973, 2\%. In Turkey there is not any administrative unit with sub-division in 
Cameroon at sub-divisional level there are 15 out of 360 SDO representing $4.1 \%$ of the global number. At the level of municipalities, in Turkey out of 81 main urban council 4 are mayors. In Cameroon 28 women are mayors in a total of 374 municipalities. With a $4.9 \%$ of women mayors in Turkey, Cameroonian women are better represented in urban council with a 7.4\%. Below table shows last 10 years major political party leadership:

Table 3: Women and political movements

\begin{tabular}{|l|l|l|l|l|c|c|}
\hline & \multicolumn{3}{|c|}{ Turkey } & \multicolumn{3}{c|}{ Cameroon } \\
\cline { 2 - 7 } & 2008 & 2013 & 2018 & 2007 & 2011 & 2018 \\
\hline $\begin{array}{l}\text { Major Political Party } \\
\text { leaders }\end{array}$ & - & - & $\begin{array}{c}1 / 90 \\
(1 \%)\end{array}$ & $\begin{array}{c}12 / 254 \\
(5 \%)\end{array}$ & $\begin{array}{c}13 / 291 \\
(4 \%)\end{array}$ & $\begin{array}{c}14 / 300 \\
(8 \%)\end{array}$ \\
\hline
\end{tabular}

Discussion: In the recent period of Turkish Political activities, even if there are cofounder of political parties such as Figen Yuksekdag and Serpil Kemalbay Pekgozegu at the gradual co-leadership of the HD Party, the main figure of women in Politics is Meral Aksener from the IYI or Good Party. On the contrary, in Cameroon in 2007, out of 254 legalised political parties 12 were conducted by women. In 2011, with a 291 political movement officially established 13 were women and in 2018, among the 300 legal political movement in the country, 14 movement have a woman as a leader. From this comparison result the fact that in Cameroon, more women are appointed at the command of political movements than what is been done in Turkey. Al above figures clearly show that in contradiction with pre-supposed expectations women representation and social life participation levels are higher in Cameroon than Turkey. This is a dramatic case because Turkey is one of the mostly developed, secular, democratic country who has based its constitution on gender equality since 1934.

On the Economic side: The economic situation of Turkey is far better than the Cameroonian one. In fact, in the 2017 World Bank report, Turkey is the first economic power in the Middle East in front of Saudi Arabia and Iran, the $7^{\text {th }}$ European economic power and the $13^{\text {th }}$ world economic country (World Bank Annual Report, 2017: 44-45). On the other hand, Cameroon is ranked $89^{\text {th }}$ worldwide. With a GGP of 34 milliards USD, for Cameroon and a 909.8 milliards USD in 2018 World Bank Statistics, it is clearly stated that Turkey is better composed than Cameroon.

However, despite a better economic environment, the comparison with the Cameroonian milieu present the Cameroonian Women better represented in the managing board of important national companies or companies having a national or international well identified importance. The main negative point as compare to what has been done in Cameroon with many important agencies that are been managed by women, is that there are no women leading major national companies. When in Cameroon less than three important national companies are conducted by women (CAMTEL, NIS, CSPH, etc.) at the only exception of AK 
Bank having as Chairman Suzan Sabanci Dincer, the majority of Turkish Companies are managed by men.

The demonstration is clear. Including Turk Telekom, THY, Turkcell, Arçelik, TUPRAS, Vestel, Efes, OTOKAR, Pegasus, Eczacıbaşı, Airport administrations etc. almost all of the main Turkish Companies realising notable performances none of them have a woman as Chief Executive Officer. Similarly, major soccer team chiefs and other sport branch chiefs are almost men dominated areas lacking women entrepreneurship. The fact almost the same in EU and Cameroon also. A situation that may change. On another level in order to promote the implication of women in the entrepreneurship, the President of the Turkish Women Entrepreneur Association known as KAGIDER is confident on the effort produce but the association to strengthen the participation of women in the national economy despite the fact that according to the national institute of Statistic of the country (the TUIK) the rate of women Entrepreneurs is $8.1 \%$. in September 2017, only 8.9 million of women out of the 30.3 million of women in capacity of work are involving themselves in activities (TUIK, 2017). In the European Economic perspective, when the men rate of employment is up to $70 \%$, the women rate is less than $30 \%$ when in Europe it is around $60 \%$.

According to KAGIDER, only $2 \%$ of women in Turkey are CEO and in the public Sector only $9.4 \%$ percent of them are Director General. In the magistracy the women are up to $35.8 \%$, women teacher in 2015 were $29 \%$ and in the same period of analysis out of 81 provinces throughout the country only $14.5 \%$ of women are member of parliament. As it is seen, there is a lot to do in gender equality. A country such as Turkey should take initial steps to bring women to the level the founder Republic M. Kemal Atatürk struggled to realize. The next issue will be handled in the context of this paper is culture.

On the Cultural and the Social side: Universities are the centres of enlightenment and cultural, scientific development. Women representation in those institutions of course will have a positive multiplying effect. The comparison in the cultural side does not present any favouring data on Turkey. Below table compares rector percentages both in Turkey and in Cameroon.

Table 4: State University Rectors in Turkey and in Cameroon

\begin{tabular}{|l|l|l|l|l|}
\hline & \multicolumn{2}{|l|}{ Turkey } & \multicolumn{2}{l|}{ Cameroon } \\
\hline & $\mathbf{2 0 1 3}$ & $\mathbf{2 0 1 8}$ & $\mathbf{2 0 1 3}$ & $\mathbf{2 0 1 8}$ \\
\hline State University Rectors & $6 / 111(5 \%)$ & $3 / 111(3 \%)$ & $1 / 8(11 \%)$ & $2 / 8(25 \%)$ \\
\hline
\end{tabular}

Discussion: First of all, in the history of the university management of Cameroon only three women have been Rector of University since the independence of the country in 1960. Including out of 206 universities state and foundation/private/vakfi Universities in Turkey only 18 are governed by women rectors which represent $8 \%$. When remain focused on the public Universities it is seen that; from 2013 to 2018 in Turkish the Number of women Rector of Public 
Universities has been divided by two. From six in 2013, in 2018 only three women are rectors in public universities in the country out of 111 Universities. In the contrary, in Cameroon in 2013 only one woman was State University Rector and the number has doubled in 20018. That corresponds to the ratio of $3 \%$ of women that are Rector in Public Universities in Turkey. In Cameroon out the only eight State Universities, two have women rectors. It is the case of Florence Uphie Chinje Melo of the University of Ngaoundere in the Adamaoua Region, Professor Nkuo Theresa Akenji of the University of Bamenda in the North West Region of the country. It represents $25 \%$ of the global universities.

As conclusion with $25 \%$ representation, women have around three times more responsibilities in state universities in Cameroon than in Turkey with only an $8 \%$. This another dramatic fact this paper brought out breaking presupposed faiths. The last issue should be taken into consideration is literacy. The below table gives solid analysis:

Table 5: Life expectancy, Alphabetisation and Fecundity in Turkey and in Cameroon

\begin{tabular}{|l|c|c|}
\hline & Cameroon & Turkey \\
\hline Life Expectancy for women & 59.9 years (2016 estimation) & 80.7 years \\
\hline Alphabetisation & $68.9 \%(2015$ estimation) & $80.6 \%(93.9 \%$ for men) \\
\hline Fecundity & 4.7 children/woman & 2.03 \\
\hline Source: CIA Torld $\quad$ Factbook; TUIK 2017; World Bank.
\end{tabular}
(https://data.worldbank.org/indicator/SP.DYN.TFRT.IN?locations=CM, 2019).

Discussion: Collected from the CIA World Factbook (2019), the World Bank Statistics and the National Institute of Statistic of Turkey (TUİK, 2019), in Cameroon the women life expectancy is 59.9 years old, when it is at 80.7 years from Turkish women. With more than 20 years of life expectancy as compare to the Cameroonians, the Turkish women have more time to impact their environment and promote the development of their country. With an alphabetisation level of $68.9 \%$ the Cameroonian women present a low level of education as compare to the one of the Turkish's one indicating a $80.6 \%$ of the women population. It simply indicates that the Turkish women are more dedicated to education than Cameroonians. The third data related to the fecundity describe a situation where in Cameroon, the ratio of child per woman is 4.7 when it is half in Turkey with 2.03. As conclusion, Cameroonian women give birth twice as often as Turkish women give birth.

Table 6: The earlier Weeding in Turkey and in Cameroon

\begin{tabular}{|l|l|l|}
\hline & Turkey & Cameroon \\
\hline Early marriage & $15 \%$ before 18 age & $31 \%$ before 18 age \\
& $1 \%$ before 15 age & $10 \%$ before 15 age \\
\hline Forced / Arranged marriage & $45 \%(?)$ & Not available \\
\hline
\end{tabular}

Source: UNICEF State of the World's Children, 2017: 181, 184. 
Discussion: According to the above table, the data collected from the publications of UNICEF indicate that in Turkey $15 \%$ of the women population are getting married before the age of 18 and only $1 \%$ before the age 15 . In contrary of the realities in Cameroon showing the double rate for women getting married before the age 18 and not less than 10 times the Turkish rate of girls getting married before the age of 15. By another side, it is impossible to fix this number but approximately with a $45 \%$ percent of forced or arranged marriage, the situation present close to the half of the Turkish women population who are not freely consenting to engage into marriages but compelled by families (UNICEF State of the World's Children, 2017, 181,184). The data from Cameroon not been available, the situation could have been different in the sense of aggravating by that side.

The conclusion that can be driven according to the exanimated table is that; the question of early marriage even if it is important in Turkey is more crucial in Cameroon than in Turkey. But the figures in Turkey also need further consideration and deep research for betterment of early women childhood era. The early or forced/arranged marriage is one of the most important threads that limit the intervention of the women in the evolution of their countries. The objective of this part is not to underline the intentions and willingness of both parts to address the issue of early marriage but analysis the deeds or concrete facts and realizations, the facts to highlight the importance give to this question.

When in Turkey, the Government has taken important measures to eliminate (by 2030) the child and early marriage with regard to its engagement manifested by the target 5.3 of the global sustainable Goals enacted by the United Nations, in Cameroon the coexistence of traditional law having among them some rules that are not always clear and constraint or compulsory on early marriage assist to the fact that some young women are forced into marriage while being young (https://www.unfpa.org/news/new-rules-help-end-child-marriage-cameroon, 2019). More precisely to face the situation, in 2009 the Committee on equality of opportunity for men and women has created at the Grand National Assembly of Turkey (TGNA) a subcommittee on Early Marriage (2010: 13-16) in order to have a better survey and monitoring of this situation in the country. Another commission founded in TGNA is Gender Equality in Opportunity prepared a report (2015: 33, 34). Same innovation hasn't been done in Cameroon. In the Green Red Yellow country, the National Assembly has not taken a so crucial decision and put into place a concrete instance nor in the National Assembly, nor in the Senate, to address the question of early and child marriage. This gap must be filled.

Even though in Turkey in 2018 the National Directorate of Religions Affairs (NTRA, in Turkish DIYANET) has published a controversial declaration disclaiming that when a young girl reaches the puberty age (which can be 13 or 14 years old), they can be married under the Islamic law, after mass critics the head of NTRA Ali Erbaş strictly has rejected this allegation saying that the normal age 
of marriage according to Turkish Code in force is 18 (https://www.ntv.com.tr/turkiye/diyanet-isleri-baskanindan-kucuk-yasta-evlilikaciklamasi,xEzGGB8PBUGWl7bliSFfEg, 2018). Also, to demonstrate its commitment to the fight against this forced and early marriage, Turkey cosponsored the 2013 and 2014 United Nation General Assembly resolution based on Child, early and forced marriage and the 2013 Human Right Council Resolution on Child early and forced Marriage. A year after in 2014, Turkey signed a joint statement at the Human Rights council related to a resolution on the child marriage issue.

Such initiative which demonstrates the importance according to the fight against that phenomena of early and forced marriage by the Turkish authorities is contrasting with a relative silence in the international milieu of Cameroon on the same question. It is obvious then to conclude that the said question has been of more preoccupations for Turkey than Cameroon.

\section{Conclusion}

In both countries where the women represent respectively $49.8 \%$ of the global population in Turkey and $50.7 \%$ in Cameroon, women are identifiable forces who participate to the development of their respective country. How are they then impacting the evolution of their country and more precisely what are the similarities and the differences in the deeds and facts of these women in their specific domain has been the key question guiding this comparative analysis formulated under the Gender and Development GAD approach. Knowing how these women have impacted the emergence of their sovereign political entities has constituted the main focus and research question of this study based on solid comparative analysis on the incidences of Turkish and Cameroonian Women in the evolution of their respective country by questioning the similarities and divergences.

In Cameroon and in Turkey, the consolidation of the nation has encountered some specific realities which have determined the level, the speed and the consistence of its development. The construction of the Fatherhood and the strengthening of its foundations which is a permanent query which is inviting in a common effort the various forces of a country in its process such as pressure groups, political parties, civil society organizations or women interventions in a single row or as a gender group. Turkish and Cameroonian women, by their implications and willingness have contributed to the emergence of their respective nation. By suggesting the hypothesis stipulating that these women have remodelled their countries realities by their analysis.

This comparative analysis which has been delimited geographically in Cameroon and in Turkey and temporally from 1923 till 2018 for the Turkish side and from 1960 till 2018 for the Cameroonian side has been conducted to address the ideas 
organized under the similitudes points on the social economic politic and cultural side at the first point and the divergences on the same aspects on another side.

It appears as similarities that in Cameroon as same as in Turkey women participate in the economic activities by organizing themselves as single person or around businesswomen associations in order to promote a global aim and collective objectives. The Turkish women as same as the Cameroonian ones are leaders of important Political parties, running presidential elections, are members of local administrations, are members of Parliament and ministers of the Republics.

However, if the above-mentioned similarities intend to get the Turkish and Cameroonian women closer on all the aspect it should be underlined that many aspects try to differentiate their integration and impact in the marches of their country. It is the case in the Territorial Commandment of women that are governors in Turkey and none in Cameroon, Women that are better represented in the Cameroonian parliament than the Turkish one, Women having a better life expectancy and a higher rate of alphabetisation or a lower fecundity expectancy in Turkey than in Cameroon, women that are more present in the university administration in Cameroon than in turkey universities as Rectors. Also there are more women Minister of the Republic in Cameroon than in Turkey, more women mayors in Cameroon, a better situation related to early arranged and forced marriage in Turkey than in Cameroon and more women Chief Execute Officer of National and major State National Companies in Cameroon than in Turkey highly managed by men.

It is not possible to access all related data in both countries simultaneously thus the context of this work is limited with accessible areas. Moreover, the fact most probably is not much different in other fields also. The most critical outcome of the study is that, despite its underdeveloped economy, challenges and disadvantages women participation into social, legal and work life in general terms better in Cameroon than Turkey. There are numerous reasons including: still existing old-feudal practices, pre-judges enforced by religious authorities, so on in Turkey causing this dramatic outcome. All those challenges need further consideration. In the dark days of Medieval Ages in Europe women generally were not recognized as an equal humankind. By enlightenment women of Europe step by step actively contributed in almost all the fields to the development of their nation. That is not the case neither in Turkey nor Cameroon. But in both countries, especially in Turkey, women participation in society in all aspects needs major, urgent betterment.

\section{Bibliography}

Arkadas, A. and Salman, T. F. (2013). Indicators for Monitoring of Violence Against Children Guidebook, UNICEF. 
Cumhuriyet. (1934). “Türk Kadını Hakların en Büyüğünü Aldı [Turkish Women granted with the highest Right]", İstanbul.

Felix, G. (2018). Black French Women and Struggle for Equality 1848-2016, U. Nebraska Press.

Hermann, B. (1928). The Division of Work According to Sex in Africa Hoe Culture, Oxford University Press.

Matematik Dünyası. (2003). Nüzhet Toydemir Gökdoğan (1910-2003), İstanbul.

Nforr, N. N. (2014). In Chains for My Country, Cursading for the British Southern Cameroons, Langaa Research and Publishing CIG: Bamenda, Cameroon.

Rose, N. (2016). "Mobilisations feminines au Cameroon Français dans les Années 1940-1950: l'ordre du genre et l'ordre Colonial", Le Mouvement Social, N. 255.

Resmi Gazete [Republic of Turkey Official Journal (RoTOJ)]. (December 3, 2001).

TBMM [Turkish Grand National Assembly]. (2010). Erken Yaşta Evlilikler Hakkında Inceleme Yapılmasına Dair Rapor [Report on Early-Marriages], Ankara.

TBMM [Turkish Grand National Assembly]. (2015). Kadın Erkek Fırsat Eşitliği Komisyonu [Commission Report on Men and Women Equality in Opportunity]. Ankara.

TUIK [Turkish State Statistics Institution]. (2018), Population data. Ankara.

UNICEF. (2017). Annual Report. Washington.

UNICEF. (2017). State of the World's Children. Washington.

Victor, J. N. (2001). Southern Cameroons, 1922-1961: A Constitutional History. Ashgate, Aldershot: Hampshire, England.

World Bank Annual Report. (2017). Washington.

Sands, R. G. and Nuccio, K. (1992). "Postmodern Feminist Theory and Social Work." Social Work, Vol. 37 (6).

African Media Initative, (n.d.). http://africanmediainitiative.org/board-members/

Une Turque dans le classement Forbes des femmes les plus puissantes du monde (7 Juin 2016). http://aujourdhuilaturquie.com/fr/une-turque-dans-leclassement-forbes-des-femmes-les-plus-puissantes-du-monde/ (Accessed: 16.03.2020).

UN Women, Europe and Central Asia, (2020). http://eca.unwomen.org/en/wherewe-are/turkey/leadership-and-political-participation (Accessed: 18.03.2021). 
Turquie: six femmes puissantes à des postes-clés, $(20$ Juliet 2016). http://madame.lefigaro.fr/societe/turquie-six-femmes-puissantes-a-des-postescles-0407106-115184 (Accessed: 04.07.2019).

Cameroun, Parité: Seulement 28 Femmes Maires Sur 374: Cameroon, (17 Jul 2017). $\quad$ http://www.camer.be/61470/11:1/cameroun-parite-seulement-28femmes-maires-sur-374-cameroon.html. (Accessed: 28.05.2020).

Survey sheds light on severity of Turkey's child marriage problem, (22 January 2018). http://www.hurriyetdailynews.com/survey-sheds-light-on-severity-ofturkeys-child-marriage-problem-126103 (Accessed: 23.06.2019).

Cameroun-Business: 5 Camerounaises dans le Top 50 des femmes d'affaires les plus influentes $d u$ continent, selon Jeune Afrique (21 Mar 2017). https://actucameroun.com/2017/03/21/cameroun-business-5-camerounaisesdans-le-top-50-des-femmes-daffaires-les-plus-influentes-du-continent-selonjeune-afrique/ (Accessed: 18.03.2021).

Dünyanın "En Güzel 100 Kadını" arasında beş Türk var [Five Turkish Women Among Worlds' Most Beautiful Women], (26 March 2017). https://balcilarblog.com/?p=18662 (Accessed: 16.07.2019).

Les 11 Futures Puissantes Entrepreneuses Camerounaises dans 25 ans (27 Decembre 2017). https://cameroonceo.com/2017/12/27/les-11-futurespuissantes-entrepreneuses-camerounaises-dans-25-ans/ 16.07.2019).

Elles sont désormais sept dames sous-préfets au Cameroun, (6 Sebtempre 2017). https://cameroon-report.com/politique/sept-sous-prefets-dames-au-cameroun/ (Accessed: 15.06.2019).

Countries and Economies, (n.d.). https://data.worldbank.org/country.

Fertility Rate, Total (Births per women) Cameroon, (2018). https://data.worldbank.org/indicator/SP.DYN.TFRT.IN?locations=CM (Accessed: 19.03.2021).

Country Profile

Turkey, (2021).https://databank.worldbank.org/data/views/reports/reportwidget.aspx?R eport_Name $=$ CountryProfile $\& I d=b 450 f d 57 \&$ tbar $=y \& d d=y \& i n f=n \& z m=n \& c o$ untry=TUR (Accessed: 19.03.2021).

Femmes De Turquie Aux Avant-Postes, (2021). https://information.tv5monde.com/terriennes/femmes-de-turquie-aux-avantpostes (Accessed: 17.06.2019).

Les femmes républicaines et la place de la femme turque dans la société d'aujourd'hui : statut juridique et politique, (2021). https://journals.openedition.org/cemoti/557 (Accessed: 10.05.2019). 
Parcours - Ces femmes turques qui ont marqué l'Histoire, (13 Decembre 2017). \#2https://lepetitjournal.com/istanbul/communaute/parcours-ces-femmesturques-qui-ont-marque-lhistoire-2-161611 (Accessed: 13.06.2019).

Centre de ressources francophones sur le VIH/sida en Afrique, (2021). https://plateforme-elsa.org/structure/renata/ (Accessed: 20.03.2021).

Yüksek Seçim Kurulu [Turkish Supreme Committee of Elections], (2021). https://sonuc.ysk.gov.tr (Accessed: 10.05.2019).

Gender Equality, Situation in Turkey, https://turkey.unfpa.org/en/node/9689 (Accessed: 10.06.2019).

$(2021)$

Association de femmes d'affaires turques (TIKAD Türkiye İş Kadınlarl Derneği), (2020). (Turquie)https://wegate.eu/fr/association-de-femmesd\%E2\%80\%99affaires-turques-tikad-t\%C3\%BCrkiye-i\%C5\%9F$\mathrm{kad} \% \mathrm{C} 4 \% \mathrm{~B} 1 \mathrm{nlar} \% \mathrm{C} 4 \% \mathrm{~B} 1-$ derne\%C4\%9Fi-turquie (Accessed: 19.03.2021).

Turquie: L'intégration des femmes dans le monde du travail, une préoccupation de l'époque, (8 March 2018). https://www.aa.com.tr/fr/titres-de-lajourn\% $3 \% \mathrm{~A} 9 \mathrm{e} /$ turquie-1-int\%C3\%A9gration-des-femmes-dans-le-mondedu-travail-une-pr\%C3\%A9occupation-de-1-\%C3\%A9poque/1083146

(Accessed: 20.03.2021).

Elections Cameroon don komot list for candidates for 2018 presidential elections, (7 August 2018). https://www.bbc.com/pidgin/tori-45100451 (Accessed: 14.06.2019).

New Parliament welcomes more women in politics to improve Turkey's Governance, (29 June 2018). https://www.dailysabah.com/elections/2018/06/29/new-parliament-welcomesmore-women-in-politics-to-improve-turkeys-governance-1530210978 (Accessed: 18.06.2019).

What's the Prevalence Rate, (2018). https://www.girlsnotbrides.org/childmarriage/turkey/ (Accessed: 18.03.2021).

111 devlet üniversitesinin sadece 3 tanesinin rektörü kadın [Only 3 Women Rector in 111 State Universities], (9 January 2018). https://www.haberturk.com/111-devlet-universitesinin-sadece-3-tanesininrektoru-kadin-1788441 (Accessed: 17.06.2019).

Ottoman Empire, (2021). https://www.history.com/topics/middle-east/ottomanempire (Accessed: 18.03.2021).

Les femmes d'affaires gagnent du terrain au Cameroun, (29 Octobre 2012). https://www.investiraucameroun.com/entreprises/2910-3693-les-femmes-daffaires-gagnent-du-terrain-au-cameroun (Accessed: 16.06.2019). 
Milat, (2018). https://www.milatgazetesi.com/trend/turkiyede-kac-bakanlik-varyeni-sistemdeki-bakanlik-sayisi/haber-180219 (Accessed: 15.06.2019).

NTV, (2021). https://www.ntv.com.tr/turkiye/diyanet-isleri-baskanindan-kucukyasta-evlilik-aciklamasi,xEzGGB8PBUGW17bliSFfEg, 2018 (Accessed: 17.03.2021).

The Presidency of the Republic of Cameroon, (2021). https://www.prc.cm/en/news/1055-ministerial-council (Accessed: 18.03.2021).

TBMM [Turkish Grand National Assembly], (2021). https://www.tbmm.gov.tr (Accessed: 18.03.2021).

Exclusive list: 50 Inflentual Women in Business, (2021). https://www.theafricaceoforum.com/en/ressources/exclusive-list-50influential-women-in-business/ (Accessed: 17.06.2019).

Istanbul et les femmes: abattre les clichés, (2021). https://www.tooistanbul.com/istanbul-femme/ (Accessed: 18.06.2019).

Turquie: Les femmes turques d'exception d'hier, d'aujourd'hui et de demain (étude), (13 March 2021). https://www.trt.net.tr/francais/programmes/2019/03/13/turquie-les-femmesturques-d-exception-d-hier-d-aujourd-hui-et-de-demain-etude-1162704 (Accessed: 19.06.2019).

We need more women in politics - Here's how to make quotas work, (11 July 2016). https://www.undp.org/content/undp/en/home/blog/2016/7/11/We-needmore-women-in-politics-Here-s-how-to-make-quotas-work.html (Accessed: 18.06.2019).

Statistics, (2021).https://www.unicef.org/infobycountry/cameroon_statistics.html (Accessed: 13.06.2019).

TBMM [Turkish Grand National Assembly]. (December 8, 1923?). Vol. 2. Ankara.

TBMM [Turkish Grand National Assembly]. (December, 1935). Amendment to Constitution: 2/131. Ankara.

Stockemer, D. (May 2007). "Why are there Differences in the Political Representation of Women in the 27 Countries of the European Union?". Perspective on European Politics and Society, Vol. 8 (4).

Kadic, H. (13 May 2014), Political Participation of Women in Turkey and the European Union perspective, (https://www.academia.edu/9623292/Political_Participation_of_Women_in_T urkey_and_the_European_Union_perspective (Accessed: 18.06.2019).

New rules to help end child marriage in Cameroon, (6 October 2016). https://www.unfpa.org/news/new-rules-help-end-child-marriage-cameroon 
Kah Walla to boycott Presidential Election, (11 May 2018). https://www.journalducameroun.com/en/kah-walla-boycott-presidentialelection/ (Accessed: 18.03.2021).

Baycanlar, S. Ç. (July, 2018). 'Nigâr Hanım'dan Günümüze Türk Edebiyatında Şair Kadınlar Uluslararası Sempozyumu, 26-28 Nisan 2018 KKTC/Magusa [International Semposium on Poet Women in Turkish Literature, April 26-28, TRNC]". Çukurova Üniversitesi Türkoloji Araştırmaları Dergisi, Vol 3 (1).

Cameroun: ces Femmes au Commandement, (4 March 2019). https://www.journalducameroun.com/cameroun-ces-femmes-aucommandement/ (Accessed: 17.06.2019).

Cameroon: US government unveils 2019 Human Rights report, (12 March 2020). https://www.lebledparle.com/international-main/1062-cameroun-les-10femmes-camerounaises-les-plus-connues-actuellement-dans-le-monde (Accessed: 19.03.2021).

Turkish Businesswomen Association, (21 March 2021). http://www.tikad.org.tr/home.html (Accessed: 19.03.2021).

Cinq femmes turques parmi les 100 plus belles du monde, (31 July 2018). https://www.redaction.media/articles/cinq-femmes-turques-parmi-100-plusbelles-monde/ (Accessed: 18.03.2021). 